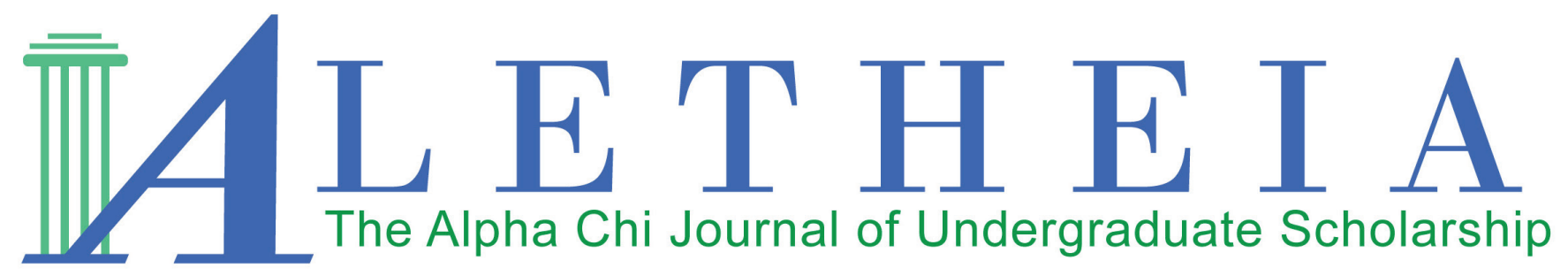

Volume 1 | Issue 2 | 2016

\title{
Self-Directed Radicals: Why Dzhokhar and Tamerlan Tsarnaev Are Lone-Wolf Terrorists
}

\author{
Thomas J. McGrath \\ Colby-Sawyer College \\ New Hampshire Alpha
}

Vol. 1(2), 2016

Article Title: Self-Directed Radicals: Why Dzhokhar and Tamerlan Tsarnaev Are Lone-Wolf Terrorists

DOI: $10.21081 / \mathrm{ax} 0076$

ISSN: 2381-800X

Key Words: lone-wolf terrorists, psychological, Internet, radical/radicalization, extremist/extremism, Muslim

This work is licensed under a Creative Commons Attribution 4.0 International License.

Author contact information is available from the Editor at editor@alphachihonor.org.

\section{Aletheia-The Alpha Chi Journal of Undergraduate Scholarship}

- This publication is an online, peer-reviewed, interdisciplinary undergraduate journal, whose mission is to promote high quality research and scholarship among undergraduates by showcasing exemplary work.

- Submissions can be in any basic or applied field of study, including the physical and life sciences, the social sciences, the humanities, education, engineering, and the arts.

- Publication in Aletheia will recognize students who excel academically and foster mentor/mentee relationships between faculty and students.

- In keeping with the strong tradition of student involvement in all levels of Alpha Chi, the journal will also provide a forum for students to become actively involved in the writing, peer review, and publication process.

- More information and instructions for authors is available under the publications tab at www.AlphaChiHonor.org. Questions to the editor may be directed to editor@alphachihonor.org.

Alpha Chi is a national college honor society that admits students from all academic disciplines, with membership limited to the top 10 percent of an institution's juniors, seniors, and graduate students. Invitation to membership comes only through an institutional chapter. A college seeking a chapter must grant baccalaureate degrees and be regionally accredited. Some 300 chapters, located in almost every state, induct approximately 12,000 members annually. Alpha Chi members have been "making scholarship effective for good" since 1922. 


\title{
Self-Directed Radicals: Why Dzhokhar and Tamerlan Tsarnaev Are Lone-Wolf Terrorists
}

\author{
Thomas J. McGrath \\ Colby-Sawyer College \\ New Hampshire Alpha
}

\begin{abstract}
Since they entered public lore in April of 2013, Dzhokhar and Tamerlan Tsarnaev have proven to be excellent examples of an emerging phenomenon known as lone-wolf terrorism. Individuals who fall into this classification of terrorism are those who direct their own tactics and are not affiliated with or carrying out the orders of any hierarchical terror organization or network. ${ }^{1}$ From the Tsarnaev's adolescence up until the immediate aftermath of the infamous Boston Marathon bombings, it is clear that these brothers follow the pattern of the lone-wolf terrorist. The factors that influenced their resorting to terror illustrate this point thoroughly. As the world is arguably close to entering what could be called the fifth wave of terrorism, deemed the "Technological Wave," Dzhokhar illustrates how influential the Internet can be in the radicalization process. ${ }^{2}$ Dzhokhar downloaded and viewed several pieces of inciting material, which could be largely responsible for his participation in the Boston Marathon bombings. Additionally, there are plenty of psychological factors that contributed heavily to the brothers' actions, particularly with Tamerlan, including undesired, frustrating developments in their personal and family lives and the classic binary outlook of "us" versus "them." These aspects of the radicalization process are compounded by the brothers' aversion to the United States government's treatment of Muslims, which caused them to sympathize with the cause of Islamic extremism. As the research illustrates, these components of their background and psychology prove that the Tsarnaev brothers are indeed quintessential examples of lone-wolf terrorists.
\end{abstract}

Key Words: lone-wolf terrorists, psychological, Internet, radical/radicalization, extremist/extremism, Muslim

\footnotetext{
${ }^{1}$ Jeffrey D. Simon, Lone Wolf Terrorism: Understanding the Growing Threat, (New York: Prometheus

Books, 2013).

2 Ibid.
} 
April 15 $5^{\text {th }}, 2013$ will forever be known not only as the $117^{\text {th }}$ Boston Marathon, but also the day of the infamous Boston bombings. On the surface, one could infer that the Tsarnaev brothers, Tamerlan and Dzhokhar, were simply troubled young men with an intense hatred for America. However, there is a lot more to them than that. In order to make sense of what happened that day, one must consider several salient factors. These factors explain the radicalization process of Tamerlan, the brothers' ostensible motivations, the integral role of the Internet in influencing Dzhokhar, and the psychological circumstances that may have compelled Tamerlan to resort to violence. In the story of the Tsarnaev brothers, there is ample evidence that shows how they fit the framework of "lone-wolf terrorists," particularly with regard to their psychological background, especially with their family, as well as the influence of the Internet in the radicalization process.

In approaching the Tsarnaevs, it is important to point out that there is a certain dichotomy when examining the brothers. While psychological forces were most influential on Tamerlan, the Internet was more influential on Dzhokhar; nevertheless, both of these claims support the broader argument that they should be categorized as lone wolves. With this in mind, the best way to study the two is to form a narrative, the events of which reflect some of the arguments of many terrorism scholars, like Jerrold Post, Jeffrey Simon, Ramon Spaaij, Michael Feldman, Clark McCauley, and Sophia Moskalenko. Some of these academics have also laid out the framework into which these men clearly fall. According to Feldman, lone-wolf terrorists are those who operate as an individual, do not belong to an organization or network, act without direct influence from a hierarchical system of leadership, and whose methods "are conceived and directed by the individual without any direct outside command or direction."3

Despite these criteria, Feldman stresses the importance of understanding the "phenomenon" of lone-wolf terrorism as "self-directed rather than solo-actor terrorism" whose assailants "often operate on behalf of established terrorist movements. ${ }^{\prime 4}$ Both Tsarnaev brothers meet all of these requirements, as an investigation re-

\footnotetext{
${ }^{3}$ Matthew Feldman. "Comparative Lone Wolf Terrorism: Toward a Heuristic Definition.” Democracy \& Security 9, no. 3 (July 2013): 270. Publisher Provided Full Text Searching File, EBSCOhost,

${ }^{4}$ Ibid.
}

vealed not only that Tamerlan "was [not] influenced or trained by Islamic militants during a trip overseas," but also that both brothers supported the cause of Muslim extremism. ${ }^{5}$ Spaaij notes that, based on ample case studies and data, lone-wolf terrorism "is principally targeted at civilians... [and] [t]he number of casualties resulting from lone wolf terrorism [have] been relatively limited." As evident in the aftermath of the bombings, three people were killed, and the main targets were all civilians. Despite these definitional characteristics, the story of the Tsarnaevs offers much more insight into how the two qualify as lone-wolf terrorists.

Of Chechen ethnicity, Tamerlan Tsarnaev was born on October 21 ${ }^{\text {st }}, 1986$ in Kyrgyzstan; Dzhokhar, from the same former Soviet republic, was born on July $22^{\text {nd }}$, 1993. ${ }^{7}$ After the brothers' parents decided to immigrate to the United States with Dzhokhar in 2002, Tamerlan stayed behind with his two sisters in Kazakhstan until July of $2003 .{ }^{8}$ The brothers both hoped that America would afford them more opportunities than their homeland, but the paths on which they embarked took dark turns. As described by many who got to know him, Dzhokhar "seemed to just fit in," was "generous," and had "lots of friends." Even this, however, speaks to part of Martha Crenshaw's argument, as quoted by Jerrold Post, that asserts, "[t]he outstanding common characteristic of terrorists is their normality." 10 However, more substan-

\footnotetext{
${ }^{5}$ Denise Lavoie, and Tom Hays. "Dzhokhar Tsarnaev, Boston Bombing Suspect, Was Influenced By Internet: Indictment." The Huffington Post, June 28 ${ }^{\text {th }}$, 2013. http://www. huffingtonpost.com/2013/06/28/dzohkhar-tsarnaev-internet-indictment_n_3515432.html.

${ }^{6}$ Ramon Spaaij. "The Enigma of Lone Wolf Terrorism: An Assessment." Studies In Conflict \& Terrorism 33, no. 9 (September 2010): 854-870. Military \& Government Collection, EBSCOhost, 864.

${ }^{7}$ CNN Staff, "Timeline: A look at Tamerlan Tsarnaev's past." CNN, April 22 $2^{\text {nd }}, 2013$. http://www.cnn.com/2013/04/21/us/ tamerlan-tsarnaev-timeline/.

${ }^{8}$ Ibid.

9 "Dzhokhar and Tamerlan: A profile of the Tsarnaev brothers." CBS News, April 23 ${ }^{\text {rd }}$, 2013. http://www.cbsnews.com/ news/dzhokhar-and-tamerlan-a-profile-of-the-tsarnaev-brothers/

${ }^{10}$ Jerrold M. Post, "Terrorist Psycho-Logic: Terrorist Behavior as a Product of Psychological Forces," in Origins of Terrorism: Psychologies, Ideologies, Theologies, States of Mind, ed. Walter Reich (Washington D.C.: Woodrow Wilson Center Press, 1998), 26.
} 
tially, one must look at what the younger brother was doing in his spare time, specifically on the Internet, despite how ostensibly well he was doing in the United States.

Despite his thriving in his new surroundings, according to the Washington Times, Dzhokhar "had radical jihadi materials on every device he owned and had been listening to jihadi messages for over a year before the attack." ${ }^{11}$ Even before detailing these electronic materials, Dzhokhar's involvement with the Internet relates to $\mathrm{Si}$ mon's argument, which asserts that " $[\mathrm{t}]$ he most important aspect of the 'Technological Wave' [of terrorism] that helps explain the growing prominence of the lone wolf terrorist is the Internet." 12 According to Lavoie and Hays, "the Internet played an important role in the suspects' radicalization... [and] [a]ll that Dzhokhar...needed to learn to make explosives with a pressure cooker was at his fingertips in jihadist files on the Internet."13 Among his files was the summer 2010 issue of Inspire, an online English-language, al-Qaeda-published magazine, which "detailed how to make bombs from pressure cookers, explosive powder extracted from fireworks and lethal shrapnel." 14 Additionally, Dzhokhar downloaded "extremist Muslim literature," including "Defense of the Muslim Lands, the First Obligation After Imam," written by Abdullah Azzam, which advocates "violence designed to terrorize the perceived enemies of Islam."15

Dzhokhar also downloaded a tract titled "The Slicing Sword, Against the One Who Forms Allegiances With the Disbelievers and Takes Them as Supporters Instead of Allah, His Messenger and the Believers." ${ }^{\prime 16}$ Consistent with Simon's argument, it is clear that these materials served as the driving "energy" behind Dzhokhar's radicalization and made him a "significant player" in terms of carrying out a heinous act of violence. ${ }^{17}$ Also,

\footnotetext{
${ }^{11}$ Maggie Ybarra. "Boston Marathon bombing trial spotlights challenge of stopping 'lone-wolf' terrorists." The Washington Times, April $6^{\text {th }}, 2015$. http://www.washingtontimes.com/news/2015/apr/6/tsarnaev-boston-marathon-bombing-trial-spotlights-/?page $=$ all.

12 Jeffrey D. Simon, Lone Wolf Terrorism: Understanding the Growing Threat, (New York: Prometheus Books, 2013), 29.

${ }^{13}$ Lavoie, and Hays.

14 Ibid.

${ }^{15}$ Ibid.

${ }^{16}$ Ibid.

${ }^{17}$ Simon, 29.
}

further pointing toward Dzhokhar's being a lone wolf, it is obvious that the Internet "provided a mechanism for [him] to become infatuated with extremist ideologies." ${ }^{18}$ Moreover, the "easy availability" of the Internet seems to have very powerfully influenced Dzhokhar and "facilitated...[his]...radicalization."" 19 Therefore, as supported by Simon's findings, Dzhokhar fits the label of a lone-wolf terrorist given how heavily the Internet influenced his subsequent decisions and actions. However, while the younger brother was becoming increasingly radicalized, the elder Tsarnaev was exposed to a number of psychological forces that ultimately led him to an act of terror and speak to his being a lone wolf.

Since coming to the United States, Tamerlan was noticeably "struggling." ${ }^{20}$ Post's principal argument states that "individuals are drawn to commit acts of violence as a consequence of psychological forces." ${ }^{21}$ Additionally, Feldman and Spaaij argue that those same forces are also present among lone wolves and are equally as influential. Feldman reasons that some of the key factors are "negatively perceived developments in personal life or career [and] direct or indirect interaction with extremist movements." 22 Similarly, Spaaij asserts that [1] one wolf terrorists tend to create their own ideologies that combine personal frustrations and aversion with broader political, social, or religious aims." ${ }^{\prime 23}$ That said, there is ample evidence that illustrates how Tamerlan fit this mold. Firstly, a sparring partner of Tamerlan, Julian Pollard, said that he felt Tamerlan "[did not] feel entirely welcome [in the United States]." Additionally, Tamerlan himself has been quoted as saying, "I [do not] have a single American friend because I [do not] understand them." ${ }^{24}$ Coupled with these telling details are several other "personal frustrations" that took place between 2008 and 2009.

Sometime around 2008, Tamerlan's father left the United States and moved to Russia, leaving his family behind..$^{25}$ Tamerlan also had a falling out with his Uncle

\footnotetext{
18 Ibid.

${ }^{19}$ Feldman.

${ }^{20}$ CBS News.

21 Post, 25.

${ }^{22}$ Feldman.

${ }^{23}$ Spaaij, 862.

${ }^{24}$ CBS News.

25 Ibid.
} 
Ruslan the following year. ${ }^{26}$ In addition to these details aligning with Feldman's and Spaaij's arguments, they also parallel Post's evidence that there is "a high incidence of fragmented families" among terrorists, which is yet another important psychological factor in the narrative. ${ }^{27}$ Also, concerning "indirect interaction with extremist movements," investigation has revealed that Tamerlan "posted videos on YouTube that feature[d] Muslim extremism" prior to the attack, which completes the amalgamation of personal turbulence and religious objectives which Spaaij defines as long-wolf terrorism. ${ }^{28}$ Tamerlan's personal hardships did not end there, as sometime soon after his family began to rupture, Tamerlan dropped out of Bunker Hill Community College, and his close friend was murdered. ${ }^{29}$ Additionally, in July of 2009, "[Tamerlan] became very violent toward [his wife] and [brainwashed] her into converting [to a] Muslim"; Tamerlan's wife also reportedly filed a domestic violence complaint against him. ${ }^{30}$ Post also notes that "aggressive people [are] disproportionately represented among terrorists," which further illustrates how large a role psychology played in the radicalization process. ${ }^{31}$ When examining Tamerlan's life prior to the attack through the lens of Feldman's, Spaaij's, and Post's arguments, it is clear that there were several impactful psychological forces as well as accompanying circumstances that corroborate the notion that Tamerlan did, in fact, qualify as a lone-wolf terrorist with a lot of "help" from some unfavorable psychological forces that exceeded his control. More importantly, though, some of these same external forces also played a large role in the radicalization process, one that aligns well with the "“us' versus 'them"” conditioning, as argued by Post.

Despite how susceptible the Tsarnaev brothers were to becoming radicalized, "authorities say there is no evidence the brothers...were affiliated with an organized terrorist group overseas." ${ }^{\prime 2}$ However, as stated by Spaaij, lone-wolf terrorists may be "more content with remaining on their own even though they may have identified

\footnotetext{
${ }^{26}$ CNN Staff.

27 Post, 25.

${ }^{28}$ CBS News.

${ }^{29}$ Ibid.

${ }^{30}$ Ibid.

${ }^{31}$ Post, 27.

${ }^{32}$ Ybarra.
}

or sympathized with the cause of existing extremist movements," which in this case was Islamic extremism..$^{33}$ The online literature and videos that the Tsarnaevs exposed themselves to are clear indicators of the cause they supported; furthermore, the note that Dzhokhar left on the boat in Watertown also shows how invested the two were in the cause. Sentences from the note include: "The U.S. Government is killing our innocent civilians," "I [cannot] stand to see such evil go unpunished," and "We Muslims are one body, you hurt one you hurt us all." ${ }^{34}$ Additionally, evidence revealed at the trial showed that Dzhokhar's actions were a "deliberate retaliation for Muslim deaths in the U.S.-led wars in Iraq and Afghanistan." 35 In analyzing this key motivator, one should look at the "us" and "them" aspect as well as the pyramid of radical opinion that McCauley and Moskalenko describe.

As noted by both Post and Spaaij, "social identification with broader political, social, or religious struggles encourages the lone wolf terrorist's dualistic categorization of the world into "us" and "them"; "36 "They'...are the source of all evil... are the source of our problems... [and] must be destroyed." ${ }^{37}$ It is clear that, based on both of the brothers' obvious identification with Islamic extremism, they began to see the world in black and white terms given the very anti-American tone in their rhetoric and their apparent motivation. This mentality is significant, as it once again proves how vital a role psychology can play and how influential and equally devastating it can be when an individual begins to perceive people and entities as either "me" or "not me."

Also, it is important to illustrate exactly how the brothers sympathized with the cause of Islamic extremism. McCauley and Moskalenko lay out a pyramid in which they describe the levels of opinion radicalization vis-à-vis potential acts of terror. Firstly, the authors describe the framework of global jihad as a series of justified actions that are carried out in the defense of Islam

\footnotetext{
${ }^{33}$ Spaaij, 864.

${ }^{34}$ Aaron Katersky, and Michele McPhee. "What Boston Marathon Bombing Suspect Dzhokhar Tsarnaev Wrote in Blood-Stained Boat." ABC News, March 10 ${ }^{\text {th }}, 2015$. http:// abcnews.go.com/US/boston-marathon-bombing-suspect-dzhokhar-tsarnaev-wrote-blood/story?id=29534415

${ }^{35}$ Ybarra.

${ }^{36}$ Spaaij, 863.

37 Post, 25.
} 
against "Western crusaders led by the United States," stating that "[i]t is the duty of good Muslims to support these actions." ${ }^{\prime 38}$ The relevance of this framework is again supported by the brothers' rhetoric and what was proven at trial; another portion of the boat note, despite being interrupted by gunshot holes, read: "Now I [do not] like killing innocent people it is forbidden in Islam but due to said (missing text) it is allowed." 39 This excerpt of the note shows how Dzhokhar saw the bombings as entirely justified given the circumstances.

In terms of the pyramid, based on the evidence previously described, the Tsarnaevs fall into the third level of the pyramid, which is categorized as Muslims "who believe that jihadis are acting in defense of Islam and that their actions are morally and religiously justified." 40 However, they would also fit the label of, as expounded by McCauley and Moskalenko, a "caring-consistency profile," which encompasses Muslims who [feel] strongly the suffering of others and a personal responsibility to reduce or revenge this suffering. ${ }^{{ }^{41}}$ Considering the relatively easy access that the brothers had to the weapons they used in the bombings, and relating back to the central argument, "the most dangerous indicator of potential for lone wolf terrorism is the combination of radical opinion with means and opportunity for radical action." "42 Therefore, it is clear that the Tsarnaevs were acting in defense of Islam in response to what they perceived as the wrongful actions of the West, leading them to adopt a mental lens that dually filtered their beliefs into "us" and "them," both of which show why and how they qualify as lone-wolf terrorists.

Following their violence, the brothers went on the run. Three days after the attack on April 18 ${ }^{\text {th }}, 2013$, the Federal Bureau of Investigation revealed the brothers' likenesses in photos and video footage via a press conference, hoping that this would expedite their capture. Late that evening, the brothers shot M.I.T. police officer

\footnotetext{
${ }^{38}$ Clark McCauley, and Sophia Moskalenko, "Toward a Profile of Lone Wolf Terrorists: What Moves an Individual From Radical Opinion to Radical Action," Terrorism and Political Violence, Volume 26, Issue 1 (2014): 69-85, http://www.tandfonline.com/doi/full/10.1080/09546553.2014.849916

${ }^{39}$ Katersky, and McPhee.

${ }^{40}$ McCauley, and Moskalenko.

${ }^{41}$ Ibid.

${ }^{42}$ Ibid.
}

Sean Collier, after which they hijacked a car. The driver of the vehicle managed to escape, though without his cell phone, after being forced to withdraw money from an ATM. The phone allowed police to narrow their search to the Watertown area. A shootout with police ensued, which resulted in the death of Tamerlan; it is still unclear if he was killed by police or by his brother running him over, but the death has since been ruled a homicide..$^{43}$ This led to a manhunt for Dzhokhar, which ended on April 19 $9^{\text {th }}, 2013$ with his surrendering in a boat in the backyard of a Watertown resident. Dzhokhar was charged with thirty crimes, to which he pleaded not guilty. On April $8^{\text {th }}, 2015$, after a federal trial that lasted roughly five months, the jury returned a verdict that found Dzhokhar guilty on all thirty counts, seventeen of which carry the death penalty.

The Tsarnaev brothers should be categorized as "lone-wolf terrorists," due to their psychological background, particularly in terms of their family lives, and from the influential nature of the Internet during the period of their radicalization before the attack. At a time when the saga of the Boston Marathon bombings is reaching a close with the end of the trial, it is apropos to examine the lives of the men responsible in terms of how their personal lives were greatly affected by a number of factors, to the point where they felt compelled to violence. Despite the lack of "history" attached to the event in question, the example of the Tsarnaev brothers has proven valuable to terrorism studies, particularly in better understanding the power of certain motivations and influences as well as making sense of acts of violence in a larger context.

\footnotetext{
${ }^{43}$ CBS News.
} 


\section{Bibliography}

CNN Staff, "Timeline: A look at Tamerlan Tsarnaev's past." $C N N$, April 22 $2^{\text {nd }}, 2013$. http://www.cnn.com/2013/04/21/ us/tamerlan-tsarnaev-timeline/ (accessed April $7^{\text {th }}$, 2015).

"Dzhokhar and Tamerlan: A profile of the Tsarnaev brothers." CBS News, April 23 $3^{\text {rd }}, 2013$. http://www.cbsnews.com/ news/dzhokhar-and-tamerlan-a-profile-of-the-tsarnaevbrothers/ (accessed April 6 $\left.6^{\text {th }}, 2015\right)$.

Feldman, Matthew. "Comparative Lone Wolf Terrorism: Toward a Heuristic Definition." Democracy \& Security 9, no. 3 (July 2013): 270. Publisher Provided Full Text Searching File, EBSCOhost (accessed April $7^{\text {th }}, 2015$ ).

Katersky, Aaron, and Michele McPhee. "What Boston Marathon Bombing Suspect Dzhokhar Tsarnaev Wrote in Blood-Stained Boat." ABCNews, March 10 ${ }^{\text {th }}, 2015$. http:// abcnews.go.com/US/boston-marathon-bombing-suspect-dzhokhar-tsarnaev-wrote-blood/story?id=29534415 (accessed April 6 ${ }^{\text {th }}, 2015$ ).

Lavoie, Denise, and Tom Hays. "Dzhokhar Tsarnaev, Boston Bombing Suspect, Was Influenced By Internet: Indictment." The Huffington Post, June 28 ${ }^{\text {th }}$, 2013. http://www. huffingtonpost.com/2013/06/28/dzohkhar-tsarnaev-internet-indictment_n_3515432.html (accessed February $11^{\text {th }}, 2015$ ).

McCauley, Clark, and Sophia Moskalenko. "Toward a Profile of Lone Wolf Terrorists: What Moves an Individual From Radical Opinion to Radical Action.” Terrorism and Political Violence. Volume 26, Issue 1 (2014): 69-85.

http://www.tandfonline.com/doi/full/10.1080/09546553. 2014.849916

Post, Jerrold M., "Terrorist Psycho-Logic: Terrorist Behavior as a Product of Psychological Forces," in Origins of Terrorism: Psychologies, Ideologies, Theologies, States of Mind, ed. Walter Reich (Washington D.C.: Woodrow Wilson Center Press, 1998), 25-40.

Simon, Jeffrey D. Lone Wolf Terrorism: Understanding the Growing Threat. (New York: Prometheus Books, 2013).

Spaaij, Ramon. "The Enigma of Lone Wolf Terrorism: An Assessment." Studies In Conflict \& Terrorism 33, no. 9 (September 2010): 854-870. Military \& Government Collection, EBSCOhost.

Ybarra, Maggie. "Boston Marathon bombing trial spotlights challenge of stopping 'lone- wolf' terrorists." The Washington Times, April 6 $6^{\text {th }}$, 2015. http://www.washingtontimes.com/news/2015/apr/6/tsarnaev-boston-marathon-bombing-trial-spotlights-/?page=all (accessed April $\left.7^{\text {th }}, 2015\right)$. 